\title{
Accidental Zinc Phosphide Poisoning among Population: A Case Report
}

\author{
Yasser El-Nahhal \\ Faculty of Science, The Islamic University-Gaza, Gaza Strip, Palestine \\ Email: y_el_nahhal@hotmail.com
}

How to cite this paper: El-Nahhal, Y. (2018) Accidental Zinc Phosphide Poisoning among Population: A Case Report. Occupational Diseases and Environmental Medicine, 6, 37-49.

https://doi.org/10.4236/odem.2018.62003

Received: February 9, 2018

Accepted: April 1, 2018

Published: April 4, 2018

Copyright $\odot 2018$ by author and Scientific Research Publishing Inc. This work is licensed under the Creative Commons Attribution International License (CC BY 4.0).

http://creativecommons.org/licenses/by/4.0/

(c) (i) Open Access

\begin{abstract}
The use of rodenticides in Gaza in the past years becomes easy due to rodent outbreak. The municipalities allow the use of rodenticides without quality control or technical supports. This situation leads to an easy purchasing of zinc phosphide or its analog. This resulted in acute poising among adults and children. Herein we reported an accidental zinc phosphide poisoning to an adult man and discussed the associated medical complications with this case. Gastric lavage followed by atropine and vitamin $\mathrm{K}$ gavage on the $1^{\text {st }}$ day of poisoning (hospital admission) resulted in a slight improvement of the case. Clinical symptoms included severe abdominal colic without losing conscious. Complete blood count (CBC) showed elevated levels of white blood cells (WBCs) and granulocytes (GRAN) levels indicating medical complication of the case. Biochemical analysis showed elevated levels of liver and cardiac biomarkers indicating potential liver and heart injuries. Continuous gavage of vitamin $\mathrm{K}$, resulted in a gradual improvement of the case. On the $4^{\text {th }}$ day of medical period, abdominal colic disappeared and $\mathrm{CBC}$ parameters became near the reference range. Consequently, the patient was set free from the hospital.
\end{abstract}

\section{Keywords}

Zinc Phosphide Poising, WBCs, GRAN, AST, ALT, CK

\section{Introduction}

Accidental poisoning of pesticides among general population rapidly increased in Gaza strip due to rodenticides application. So far an outbreak of rodents in Gaza enhanced the chemical control to reduce the populations of rats. Municipalities, ministry of health and ministry of agriculture approve rodent control even by participation of the local communities. This decision enhanced pesticide 
marketing with less quality control. Zinc phosphide was the key product for fast rodent control using food poisoning techniques [1]. It is commercially available in different formulations containing of $320 \mathrm{~g}$ zinc phosphide $/ \mathrm{kg}$.

Accidental poising of pesticides may occur during field application [2] [3] [4] [5], suicidal attempts [6], occupational exposure [7] and other indirect ways of exposure [8]-[21].

Previous studies from Gaza [22]-[28] did not report zinc phosphide toxicity. The limitation is that they did not give considerable attention to zinc phosphide poisoning. To date, this is the $1^{\text {st }}$ report from Gaza to highlight and discuss zinc phosphide poisoning. However, here below we presented a case report of zinc phosphide poisoning from Gaza with a young man, 31 years old and discuss its medical consequences.

So far Zinc phosphide is an inorganic pesticide, solid at room temperature, and has a grey color but often dark or even black. It is highly toxic in acute exposure to humans, its acute oral LD50 for rat $45.7 \mathrm{mg} / \mathrm{kg}$ [29]. It is classified as IB [30].

\section{Materials and Method}

Mr. Ann F. an adult man, 31 years old, married, has two children, was preparing food poisoning for rat control in his house garden in Khanyounis city using zinc phosphide as an active ingredient. He mixed the zinc phosphide with animal food and presented to the rat. He felt sick at the end of the preparation, hypoactive with abdomen colic, his parent brought him to the European hospital in the south part of Gaza.

During the interview with his parents, they claimed that he was preparing food poisoning for rats. They also brought with them the empty package of the used pesticide. It appeared to us that it was Zinc phosphide. This information made the medical treatment easier than other poisoned cases without historical information. As we elaborated above it is a rodenticide, very toxic according to WHO classification.

\subsection{Medical Treatment}

Following the international guideline described previously for pesticide poisoning [30], the clothes of Mr. Ann F. were removed and his skin was washed several time with water and soup to insure contamination free environment.

Immediately, the medical team performed gastric lavage several time to remove all zinc phosphide. This step repeated several time to insure complete removal of zinc phosphide. In one attempt, activated charcoal was used to enhance and insure optimal removal.

Mr. Ann was admitted in the intensive care unit for observation and complete medical treatment. Venous blood samples were drawn for complete blood chemical analysis, and for Heart enzyme and liver biomarkers determination. These steps were repeated every day to monitor the treatment weather in the right direction or not. 
Mr. Ann received $10 \mathrm{mg}$ atropine in $500 \mathrm{~mL}$ normal saline solution every $6 \mathrm{~h}$ on the $1^{\text {st }}$ day (on admission) only then it was stopped, and replaced by vitamin K.

\subsection{Analysis of Blood and Urine}

Urine and blood samples $10 \mathrm{ml}$ each were drawn on admission and repeated during the medical treatments for zinc phosphide analysis using previous methods [31] [32] [33]. In this procedure samples were digested with nitric acid at $65^{\circ} \mathrm{C}$ for $24 \mathrm{hr}$ then temperature was raised up to 135 for several $\mathrm{hr}$ up to have a clear solution after words zinc concentrations in the samples were determined using Inductive coupled plasma analyzer (ICP).

\subsection{Complete Blood Count (CBC) Measurements}

Blood samples were drawn every day for $\mathrm{CBC}$ and enzymatic measurements. $\mathrm{CBC}$ measurement was performed according to the standard method of ministry of health [34]. As described recently [35], activities of ALT, AST, and ALP were taken as indicators of liver injury due to zinc phosphide poisoning. The activity of alkaline phosphatase (ALP) was determined according to Kind and King [36] using commercially supplied kits, ref number 10441 9910021, lot 60112654 purchased from DiaSys, Germany through Israeli company. AST and ALT activities were measured based on Reitman and Frrankel [37] using a commercially available kit for AST ref numbers 126019910021, lot 60112076 and ALT kit ref BXC0213D, lot 162254 from Bio-Merieux purchased from Israeli company.

Percentage of enzyme activation was calculated accord to Equation (1), [38]

$$
\% \text { Enzyme activation }=100 * \frac{\left(E A_{t}-E A_{c}\right)}{E A_{c}}
$$

where $E A_{c}$ and $E A_{t}$ are the enzyme activity of the control group (reference range) and treatment (poisoned case) respectively.

\section{Results}

\subsection{Blood Parameters}

In Table 1 we present the results of blood analysis of Mr. Ann F. It can be observed that WBC was higher than that of the reference range on the $1^{\text {st }}$ day of poisoning (on admission). Then the level gradually reduced and became closer to the lower limit of the reference range. This result indicates that WBC was involved in the detoxification process of zinc phosphide. Furthermore, granulocytes (GRAN) level was several times higher than the reference range. Due to gastric lavage, the level was reduced but still in the cutoff range, indicating some damage was occurred. Hemoglobin level was $15.4 \mathrm{~g} / \mathrm{dl}$, closed to the upper limit of reference range. Then the level was reduced. PLT level was high on the $1^{\text {st }}$ day of admission then severely reduced on the $2^{\text {nd }}$ and $3^{\text {rd }}$ days. On the $4^{\text {th }}$ day PLT level went up indicating recovery. 
Table 1. Blood analysis of the patient during the intensive care unit hospitalization.

\begin{tabular}{cccccc}
\hline Parameter & $1^{\text {st }}$ day & $2^{\text {nd }}$ day & $3^{\text {rd }}$ day & $4^{\text {th }}$ day & Reference range \\
\hline WBC & 15.9 & 10.6 & 7.2 & 5.7 & $4.5-13.5(\mathrm{k} / \mu \mathrm{L})$ \\
RBC & 4.89 & 4.09 & 4.09 & 4.52 & $4.5-5.3(\mathrm{~m} / \mu \mathrm{L})$ \\
HCT & 45 & 38.2 & 37.7 & 41.4 & $37-49(\%)$ \\
MCH & 13.5 & 30.6 & 30.3 & 30.3 & $25-35$ \\
RDW & 13.9 & 13.5 & 13.3 & 13.5 & $11.5-14.5(\%)$ \\
LYM & 1 & 1.4 & 1.4 & 1.3 & $0.6-4.1(\%)$ \\
GRAN & 14.4 & 8.5 & 5.2 & 4 & $2.0-4.1(\%)$ \\
HGB & 15.4 & 12.5 & 12.4 & 13.7 & $12-16(\mathrm{~g} / \mathrm{dL})$ \\
MCV & 92.1 & 93.5 & 92.1 & 91.6 & $78-102$ \\
MCHC & 34.2 & 32.7 & 32.9 & 33.1 & $31-37$ \\
PLT & 209 & 163 & 152 & 229 & $140-450(\mathrm{k} / \mu \mathrm{L})$ \\
\hline
\end{tabular}

where $\mathrm{WBC}=$ white blood count; $\mathrm{RBC}=$ red blood count; $\mathrm{HCT}=$ hematocrit; $\mathrm{MCH}=$ mean corpuscular hemoglobin; RDW = red blood distribution percent; LYM = lymphocyte cell percent; GRAN = granulocyte cell percent; $\mathrm{HGB}=$ hemoglobin; $\mathrm{MCV}=$ mean corpuscular volume; $\mathrm{MCHC}=$ mean corpuscular hemoglobin concentration; PLT $=$ platelet count.

\subsection{Responses of Liver and Hear Enzymes}

Table 2 shows the influences of zinc phosphide on activities of liver function tests, and heart enzyme activities. It can be observed that on the $1^{\text {st }}$ day (on admission) the levels of AST, CK total and CK-MB are above reference range and tended to increase higher than the reference range indicating hepatotoxicity and cardiac toxicity.

Furthermore, AST activity remained higher than reference range in the last three days of medical treatments. This indicates liver cell injury. It is well known in the literature that increasing AST and ALT levels often represent hepatocyte injury with altered cell membrane permeability, causing the excessive leakage of transaminases. This event may be appeared due to the interaction of $\mathrm{PH} 3$ with cytochrome coxidase as in reaction Equation (2) and causing mitochondrial damage. In addition CK Total remained several time higher than the reference range indicating high potential of cardiac toxicity and medical complications.

So far, elevation level of enzymes based on Ref [2] were in the range of 1.22 3.2 folds higher than the reference range. This indicates the magnitude of damage on different organs. Moreover, Table 3 shows the concentrations of total and direct Bilirubin. It is obvious that both values enlarged several times above normal range on the $4^{\text {th }}$ day of medical period indicating developmental toxicity. So far both values confirm liver cell damage and injury as indicated in Table 2 .

\subsection{Effects on Precipitation Parameters}

In Table 3, we presented the value of INR, the important indicator of blood clotting as affected by zinc phosphide poisoning. Regardless to the apparent variations on the values in Table 3. Statistical analysis did not discriminate significant 
Table 2. Activity of liver and heart enzymes profiles during poisoning.

\begin{tabular}{ccccccc}
\hline $\begin{array}{c}\text { Measured } \\
\text { enzyme }\end{array}$ & $1^{\text {st }}$ day & $2^{\text {nd }}$ day & $3^{\text {rd }}$ day & $4^{\text {th }}$ day & $\% \mathrm{E}$ & Reference range \\
\hline ALT & $12 \pm 3$ & $18 \pm 3$ & $21 \pm 3$ & $19 \pm 4$ & - & $1-43(\mathrm{u} / \mathrm{l})$ \\
AST & $47 \pm 5$ & $58 \pm 5$ & $82 \pm 5$ & $82 \pm 12$ & $1.27-2.22$ & $0-37(\mathrm{u} / \mathrm{l})$ \\
ALP & $259 \pm 12$ & $187 \pm 15$ & $\mathrm{ND}$ & $265 \pm 25$ & - & $100-300(\mathrm{u} / \mathrm{l})$ \\
CK TOTAL & $374 \pm 15$ & $2073 \pm 120$ & $\mathrm{ND}$ & $\mathrm{ND}$ & $2.99-16.6$ & $26-125(\mathrm{u} / \mathrm{l})$ \\
CK-MB & $80 \pm 6$ & 45 & $44 \pm 5$ & $39 \pm 6$ & 3.2 & up to $25(\mathrm{u} / \mathrm{l})$ \\
LDH & $1378 \pm 25$ & $\mathrm{ND}$ & $\mathrm{ND}$ & $670 \pm 30$ & $3.1-1.49$ & $225-450(\mathrm{u} / \mathrm{l})$ \\
Amylase & $140 \pm 13$ & $94 \pm 9$ & $\mathrm{ND}$ & $43 \pm 5$ & 1.12 & $25-125(\mathrm{u} / \mathrm{l})$ \\
\hline
\end{tabular}

$\% \mathrm{E}$ represents elevation of enzyme activity due to poisoning. Creatine kinase (CK), lactic acid dehydrogenase (LDH), alkaline phosphatase (ALP), Aspartate aminotransferase (AST), and Alanine aminotransferase (ALP).

Table 3. Precipitation parameters.

\begin{tabular}{cccccc}
\hline Measured parameter & $1^{\text {st }}$ day & $2^{\text {nd }}$ day & $3^{\text {rd }}$ day & $4^{\text {th }}$ day & Reference range \\
\hline PT-Seconds & $16.9 \pm 2.5$ & $\mathrm{Nd}$ & $\mathrm{Nd}$ & $16 \pm 3$ & $11-15 \mathrm{sec}$ \\
INR & $1.33 \pm 0.22$ & $\mathrm{Nd}$ & $\mathrm{Nd}$ & $1.26 \pm 0.2$ & $(0.8-1.2)$ \\
PT-Activity & $62 \pm 5$ & $\mathrm{Nd}$ & $\mathrm{Nd}$ & $68 \pm 8$ & \\
\hline
\end{tabular}

differences between the measured values and corresponding reference range.

It is obvious that prothrombin precipitation time (PT) is reduced from $16.9 \pm$ 2.5 second (the 1st analysis after poisoning) to $16 \pm 3$ second after three days of ICU hospitalization (Vitamin K was given every day).

\subsection{Zinc Residue Analysis}

Inductive coupled plasma analyzer did not detect zinc in urine or blood. This was probably due to the fact that gastric lavage removed high fraction of zinc phosphide. Moreover, zinc phosphide may be excreted from the body throughout the feces path way not by urine.

\section{Discussion}

The idea behind using gastric lavage, atropine and vitamin $\mathrm{K}$ gavage, is that the medical protocol of poisoning cases includes performance of these steps immediately on arrival to the hospital unless the case is unconscious. Additionally, gavage of atropine to the poisoning cases is the $1^{\text {st }}$ step of medical treatments regardless to the fact that poisoning case occurred through organophosphorus poisoning or zinc phosphide and its analogs.

\subsection{Mode of Action and Toxicity}

The presented results indicate acute poising of Mr. Ann due to accidental zinc poising. It was noticed that after accidental inquisition of zinc phosphide, Mr. 
Ann began vomiting, abdominal colic, hypoactivity, headache. These symptoms appeared in the $1^{\text {st }}$ day of poisoning. The appearance of these symptoms may be explained by the fact that zinc phosphide is being hydrolyzed in the stomach under acidic media to form hydrogen phosphide and zinc ion according to equation (Equation (2)).

$$
\begin{array}{r}
\mathrm{Zn}_{3} \mathrm{P}_{2}+\mathrm{H}^{+} \rightarrow \mathrm{PH}_{3}+\mathrm{Zn}^{2+} \\
K_{1}=\frac{(\mathrm{Zn})\left(\mathrm{PH}_{3}\right)}{\left(\mathrm{Zn}_{3} \mathrm{P}_{2}\right)\left(\mathrm{H}^{+}\right)}
\end{array}
$$

where $K_{1}$ is the reaction constant and represents formation of toxic molecules $\left(\mathrm{PH}_{3}\right)$ hydrogen phosphide in the stomach of human being. This reactive molecule tends to react with cytochrome $\mathrm{c}$ oxidase (mitochondrial enzymes responsible for respiration of cells) to form inhibited enzyme as in Equation (3).

$$
\begin{gathered}
\mathrm{PH}_{3}+\text { Cytochrome } \mathrm{C} \text { oxidase } \rightarrow \text { PH-Cytochrome } \mathrm{C} \text { complex } \\
K_{2}=\frac{\left(\mathrm{PH}_{3}-\text { Cytochrome } \mathrm{C} \text { oxidase }\right)}{(\mathrm{PH} 3)(\text { Cytochrome } \mathrm{C} \text { oxidase })}
\end{gathered}
$$

where $K_{2}$ is the inhibition constant and represents the magnitude of toxicity.

$$
\mathrm{Zn}^{2+}+\text { Trypsin (gastric enzyme) } \rightarrow \text { [Trypsin-Zn-Trypsin] complex }
$$

It can be observed that the quantity of zinc phosphide ingested, the potential toxicity increased as obvious from Equation (3), that shows, $\mathrm{PH}_{3}$ production is a function with the initial concentration of zinc phosphide being ingested. In addition, the acidity of the stomach is a key factor on producing $\mathrm{PH}_{3}$, so far in a less stomach acidity or in alkaline stomach, reaction Equation (2) would not have occurred, consequently no production of active molecule $\left(\mathrm{PH}_{3}\right)$ and toxic symptoms neither appear on the live nor on the heart. Moreover, the reaction in Equation (4) can be responsible on the abdominal colic and other symptoms. The release of the clinical symptoms after the $1^{\text {st }}$ day may be attributed to the fact that large fraction of zinc phosphide being removed by gastric lavage and the remaining part may be execrated throughout the feces pathway.

This discussion is a driving force towered developing medical treatment for gastric lavage that can immediately change the gastric media from sever acidic to neutral or slightly alkaline that can stop reaction in Equation (2). In addition, it can be suggested that adding activated charcoal, clay, and/or organo-clay may drastically reduce the toxicity due to possible adsorption between zinc phosphide and those materials. This suggestion is supported previous results of [39] [40] that revealed high adsorption between organo-clays and organic and inorganic molecules.

So far accidental swilling of a low concentration of zinc phosphide may be attached by WBC as shown by high level of WBC on the $1^{\text {st }}$ day (on admission) and be prevented to reach the liver accordingly no anticoagulation may occur. Our explanation is supported by the results in Table 1, which showed a decrease in WBC during the ICU medication. Moreover, the data in Table 3, indicate 
nearly a high value of INR above normal range $(0.8-1.2)$. This suggests that prothrombin formation was inhibited, this is also obvious from the high value of prothrombin precipitation time (PT) Table 3. In due time a reduction in the value was obtained due to Vitamin $\mathrm{K}$ gavage to the patient. Our results agree with previous reports [2] [3] who found similar observation in medical treatment of Chlorpyrifos poisoning.

This disappearance of zinc phosphide in blood and urine samples may be attributed by the fact that zinc phosphide can be hydrolyzed as in Equation (2) not only in the stomach but also under acidic environmental conditions and producing phosphine $\left(\mathrm{PH}_{3}\right)$ which can be inhaled and reacted with cytochrome $\mathrm{c}$ oxidase as in Equation (3). Our explanation is in accordance with previous reports [41] [42].

\subsection{Further Consequences of Zinc Phosphide Poisoning}

In Figure 1, we presented the ratios of AST to ALT, AST and to platelet. It has been documented that AST/ PLT index is a reliable marker for prediction of liver fibrosis [43] [44]. Our calculated values for AST/ALT and AST/PLT at any point is above 1.5 suggesting severe liver injury. This suggestion is in accordance with [45].

\subsection{Environmental Relevance of Pesticide Poisoning}

It is well known in the literature that zinc phosphide poisoning is a significant cause of morbidity and mortality in poor countries where pesticide application occurred with caseless attention to the safety regulations. It has been shown that a dosage of 4 to $5 \mathrm{~g}$ of zinc phosphide which equivalent to LD50 value of (55 - 70 $\mathrm{mg} / \mathrm{kg}$ ) had resulted in human deaths in acute toxicity [46]. The presented case herein developed severe toxicity but finally with successfully medical treatment the patient recovered.

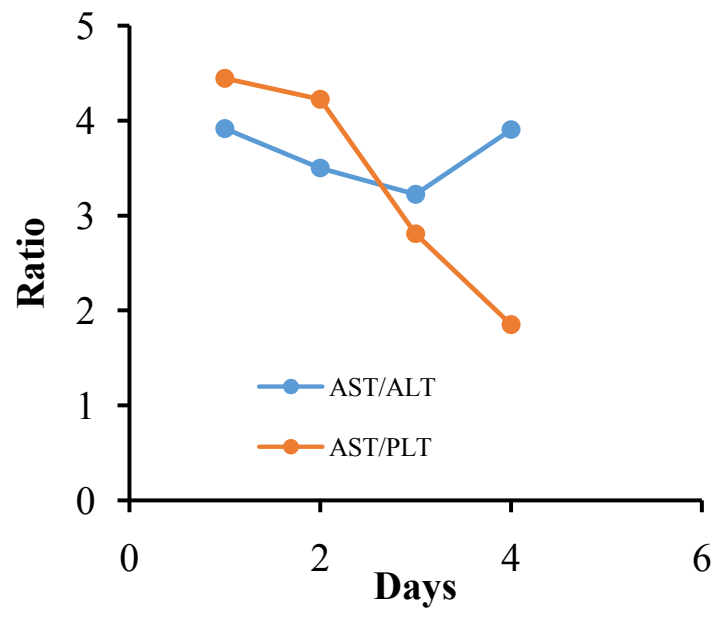

Figure 1. Aspartate aminotransferase (AST) to alanine aminotransferase (ALT) ratio, aspartate aminotransferase to platelet level during the medical period. 
So far, the environmental relevance of this work emerges from the fact that poisonous cases among population may occur due to occupational exposure, swelling of contaminated food, drug poisoning, pesticides poisoning and poisoning of industrial chemicals. So far, previous investigations [47]-[57] revealed that poisoning among population may occur via ingestion of contaminated food and water and contaminated air.

Recent investigation reported poisoning cases among farm workers [58] [59] due to using pesticide containers as domestic tools. Recent survey [2] [3] indicated long term toxicity among farmers. So far long term toxicity of pesticides in Gaza Strip have been documented [9] [10] [11] [12] [13].

Furthermore, spraying pesticides in farms have been shown to damage non-target organisms such as cyanobacteria [22] [15], plants ([53], fish ([54] [55]. So far many authors devoted tremendous efforts to reduce the toxicity of farmers, this included clay based and/or organo-clay formulations [18] [19] [20] [21] [22] [60]-[68]. Regardless of these scientific reports accidental poisoning may not be stopped but it has to be reduced to the lowest level.

\section{Conclusion}

Accidental poisoning may be stopped throughout careful attention during pesticide application. Nevertheless, it may suddenly occur due to misunderstanding the rules and regulations and probably due careless attention during work. Nevertheless, accidental poisoning may occur due to environmental conditions. However, poising with zinc phosphide created liver damage and cardiac toxicity. Careful attention must be taken during work with organophosphorus pesticide. This should include musk during work to avoid breathing or ingestion of small amounts of zinc phosphide.

\section{Acknowledgements}

Special thanks to the Alexander von Humboldt foundation for a Research Fellowship at Leipzig University and BAM institute Germany. I would also like to thank my students at faculty of science for helping me in collecting field data.

\section{Ethical Statement}

This study was not funded by any organization.

Compliance with ethical standards.

\section{Conflict of Interest}

Author declares that he has no conflict of interest.

\section{References}

[1] El-Nahhal, Y. (2004) Contamination and Safety Status of Plant Food in Arab Countries. Journal of Applied Science, 4, 411-417.

https://doi.org/10.3923/jas.2004.411.417 
[2] El-Nahhal, Y. (2016) Biochemical Changes Associated with Long Term Exposure to Pesticide among Farmers in the Gaza Strip. Occupational Diseases and Environmental Medicine, 4, 72-82. https://doi.org/10.4236/odem.2016.43009

[3] El-Nahhal, Y. (2017) Acute Poisoning among Farmers by Chlorpyrifos: Case Report from Gaza Strip. Occupational Diseases and Environmental Medicine, 5, 47-57 https://doi.org/10.4236/odem.2017.52005

[4] Al-Arifi, S.N., Al-Agha, R.M. and El-Nahhal, Z.Y. (2013) Hydrogeology and Water Quality of Umm Alradhma Aquifer, Eastern Saudi Arabia. Journal of Environment and Earth Science, 3, 118-127.

[5] Al-Kurdi, S., Al-Louh, M.O., Al-Agha, M.R. and El-Nahhal, Y. (2018) Development of Analytical Method for the Detection of Nemacur Residues in Cucumber Fruits. American Journal of Analytical Chemistry, 9, 64-76. https://doi.org/10.4236/ajac.2018.91006

[6] El-Nahhal, Y. (2017) Suicidal Attempt Using Racumin: A Case Report. Open Access Journal of Toxicology, 2, OAJT.MS.ID.555579.

[7] El-Nahhal, Y. (2013) Alcohol like Syndrome: Influence of Increased $\mathrm{CO}_{2}$ Concentration in the Respiration Air. Journal of Environment and Earth Science, 3, 222-227.

[8] Nir, S., Undabeytia, T., Yaron-Marcovich, D., El-Nahhal, Y., Polubesova, T., Serban, C., Rytwo, G., Lagaly, G. and Rubin, B. (1999) Optimizing Adsorption of Hydrophobic Herbicides on Organo-Clays. The XIVth International Plant Protection Congress (IPPC). 25-30 July 1999, Jerusalem, 12.

[9] Schecter, A., Papke, O., Ryan, J., Furst, P., Isaac, J., Hrimat, N., Neiroukh, F. Safi, J., El-Nahhal, Y., Abu El-Haj, S., Avni, A., Richter, E., Chuwers, P. and Fischbein, A. (1997) Dioxins, Dibenzofurans and PCBs in Human Blood, Human Milk and Food from Israel, The West Bank and Gaza. Organohalogen Compounds, 33, 457-461.

[10] Schecter, A., Papke, O., Isaac, J., Hrimat, N., Neiroukh, F., Safi, J. and El-Nahhal, Y. (1997) 2,3,7,8 Chlorine Substituted Dioxins and Dibenzofuran Congeners in 2,4-D, 2,4,5-T and Pentachlorophenol. Organohalogen Compounds, 32, 51-55.

[11] Polubesova, T., El-Nahhal, Y., Nir, S., Rytwo, G., Serban, C., Margulies, L. and Rubin, B. (1998) Adsorption of benzyltrimethylammonium to Montmorillonite: Application to Herbicide Formulation. Proceedings of the 16th Word Congress of Soil Science Volume I Symposium, Montpellier, 149.

[12] El-Nahhal, Y. and Safi, J. (2008) Removal of Pesticide Residues from Water by Organo-Bentonites. 12th International Water Technology Conference, Alexandria, 1711-1724.

[13] El-Nahhal, Y. and Safi, J. (2010) Adsorption of Bromoxynil to Modified Bentonite: Influence of $\mathrm{pH}$, and Temperature. Journal of Pesticide Science, 35, 333-338. https://doi.org/10.1584/jpestics.G09-41

[14] El-Nahhal, Y. and Safi, J. (2012) Removal of Organic Pollutants from Water by Modified Bentonite. In: Soundararajan, R.P., Ed., Pesticides-Advances in Chemical and Botanical Pesticides, InTech, London, Chapter 5, 93-102. https://doi.org/10.5772/50598

[15] Bornstein, R., Safi, J., El-Nahhal, Y., Isaac, J., Rishmawi, Kh., Luria, M., Mahrer, Y., Ranmar, D. and Weinroth, E. (2001) Transboundary Air-Quality Effects from Urbanization. SJSU Report to USAID.

[16] Heinze, S., Chen, Y., El-Nahhal, Y., Hadar, Y., Jung, R., Safi, J., Safi, M., Tarchitzky, J. and Marschner, B. (2014) Small Scale Stratification of Microbial Activity Parame- 
ters in Mediterranean Soils under Freshwater and Treated Wastewater Irrigation. Soil Biology and Biochemistry, 70, 193-204. https://doi.org/10.1016/j.soilbio.2013.12.023

[17] El-Nahhal, Y., Nir, S., Polubesova, T., Margulies, L. and Rubin, B. (1997) Organo-Clay Formulations of Alachlor: Reduced Leaching and Improved Efficacy. Proceedings of Brighton Crop Protection Conference, Weeds, Vol. 1, 21-26.

[18] Al-Arifi, S.N., Al-Agha, R.M. and El-Nahhal, Z.Y. (2013) Environmental Impact of Landfill on Groundwater, South East of Riyadh, Saudi Arabia. Journal of Natural Sciences Research, 3, 222-242.

[19] Safi, J., Abou Foul, N., El-Nahhal, Y. and El-Sebae, A. (2001) Monitoring of Pesticide Residues on Green Pepper, Potatoes, Vicia faba, Green Bean and Green Peas in Gaza Governorate (PNA), Palestine. Journal of Pest Control and Environmental Sciences, 9, 55-72.

[20] El-Nahhal, Y., Nir, S., Polubesova, T., Margulies, L. and Rubin, B. (1999) Movement of Metolachlor in Soil: Effect of Organo-Clay Formulation. Pesticide Science, 55, 857-864. https://doi.org/10.1002/(SICI)1096-9063(199908)55:8<857::AID-PS24>3.0.CO;2-P

[21] El-Nahhal, Y., Nir, S., Polubesova, T., Margulies, L. and Rubin, B. (1998) Leaching, Phytotoxicity and Weed Control of New Formulations of Alachlor. Journal of Agricultural Food Chemistry, 46, 3305-3313. https://doi.org/10.1021/jf971062k

[22] Safi, J., Awad, Y. and El-Nahhal, Y. (2014) Bioremediation of Diuron in Soil and Cyanobacterial Mat. American Journal of Plant Sciences, 5, 1081-1089. https://doi.org/10.4236/ajps.2014.58120

[23] Safi, J., Abu Foul, N., El-Nahhal, Y. and El-Sebae, A. (2002) Monitoring of Pesticide Residues on Cucumber, Tomatoes and Strawberries in Gaza Governorates, Palestine. Nahrung/ Food, 46, 34-49.

[24] Safi, J., Soliman, H. and El-Nahhal, Y. (2000) Surveillance of School Children Prevalence of Infectious Parasites in Beach Camp at Gaza Palestine. Journal of Pest Control and Environmental Sciences, 8, 123-134.

[25] Safi, J.M., El-Nahal, Y.Z., Soliman, S.A. and EL-Sebae, A.H. (1993) Mutagenic and Carcenogenic Pesticides Used in Agricultural Environment of Gaza Strip. The Science of the Total Environment, 132, 371-380. https://doi.org/10.1016/0048-9697(93)90145-V

[26] El-Nahhal, Y. and Radwan, A. (2013) Human Health Risks: Impact of Pesticide Application. Journal of Environment and Earth Science, 3, 199-209.

[27] El-Nahhal, Y. and Harrarah, S. (2013) Contamination of Groundwater and Associated Disease: Case Study from Khan Younis Governorate, Gaza, PNA. Journal of Environment and Earth Science, 3, 147-153.

[28] El-Nahhal, Y. and Safi, J. (2002) Contamination of Plant Food by Organic Chemicals: Food Safety Status: Problems and Recommendation. Proceeding of FAO-UNIRegional Workshop on Post-Harvest in the West Asia and North Africa Region, Cairo, 3-6 February 2002, 501-507.

[29] Tomlin, S.C. (2000) The Pesticide Manual. 12th Edition, British Crop Protection Council, Surry.

[30] WHO (2008) Clinical Management of Acute Pesticide Intoxication: Prevention of Suicidal Behaviours. WHO Library Cataloguing-in-Publication Data. http://apps.who.int/iris/bitstream/10665/44020/1/9789241597456_eng.pdf

[31] El-Nahhal, Y. (2006) Contamination of Groundwater with Heavy Metals in Gaza. 
10 th International Water Technology Conference, Alexandria, 1139-1150.

[32] El-Nahhal, I., Al-Najar, H. and El-Nahhal, Y. (2014) Physicochemical Properties of Sewage Sludge from Gaza. International Journal of Geosciences, 5, 586-594. https://doi.org/10.4236/ijg.2014.56053

[33] El-Nahhal, I., Al-Najar, H. and El-Nahhal, Y. (2014) Cations and Anions in Sewage Sludge from Gaza Waste Water Treatment Plant. American Journal of Analytical Chemistry, 5, 655-665. https://doi.org/10.4236/ajac.2014.510073

[34] Ministry of Health (2015) Annual Report. Gaza.

[35] El-Nahhal, Y. and Lubadd, R. (2018) Acute and Single Repeated Dose Effects of Low Concentrations of Chlorpyrifos, Diuron, and Their Combination on Chicken. Environmental Science and Pollution Research International. https://doi.org/10.1007/s11356-018-1313-y

[36] Kid, P.R.N. and King, E.G. (1954) Estimation of Plasma Phosphatase by Determination of Hydrolysed Phenol with Amino-Antipyrine. Journal of Clinical Pathology, 7, 322-326. https://doi.org/10.1136/jcp.7.4.322

[37] Reitman, S. and Frankel, S. (1957) A Colorimetric Method for Determination of Serum Glutamate Oxaloacetic Acid and Pyruvic Acid Transaminases. American Journal of Clinical Pathology, 29, 56-63. https://doi.org/10.1093/ajcp/28.1.56

[38] El-Nahhal, Y., EL-dahdouh, N., Hamdona, N. and Alshanti, A. (2016) Toxicological Data of Some Antibiotics and Pesticides to Fish, Mosquitoes, Cyanobacterial Mats and to Plants. Data in Brief, 6, 871-880. https://doi.org/10.1016/j.dib.2016.01.051

[39] El-Nahhal, Y. and Safi, J. (2004) Adsorption Behavior of Phenanthrene on Organoclays under Different Salinity Levels. Journal of Colloid and Interface Science, 269, 265-273. https://doi.org/10.1016/S0021-9797(03)00607-6

[40] El-Nahhal, Y. and Safi, J. (2004) Stability of an Organo Clay Complex: Effects of High Concentrations of Sodium Chloride. Applied Clay Science, 24, 129-136. https://doi.org/10.1016/j.clay.2003.01.002

[41] Burkhart, K.K. (2006) Methyl Bromide and Other Fumigants. In: Flomenbaum, N.E., Goldfrank, L.R., Hoffman, R.S., Howland, M.A., Lewin, N.A. and Nelson, L.S., Eds., Goldfrank's Toxicologic Emergencies, McGraw-Hill, New York, 1556-1563.

[42] Chomchai, S. (2004) Phosphine and Phosphides. In: Olson, K.R., Ed., Poisoning and Drug Overdose, McGraw Hill, New York, 306-307.

[43] Wai, C.T., Greenson, J.K., Fontana, R.J., et al. (2003) A Simple Noninvasive Index Can Predict Both Significant Fibrosis and Cirrhosis in Patients with Chronic Hepatitis C. Hepatology, 38, 518-526. https://doi.org/10.1053/jhep.2003.50346

[44] Xiao, G., Yang, J. and Yan, L. (2015) Comparison of Diagnostic Accuracy of Aspartate Aminotransferase to Platelet Ratio Index and Fibrosis-4 Index for Detecting Liver Fibrosis in Adult Patients with Chronic Hepatitis B Virus Infection: A Systemic Review and Meta-Analysis. Hepatology, 61, 292-302. https://doi.org/10.1002/hep.27382

[45] Vongbhavit, K. and Underwood, A.M. (2017) Predictive Value of the Aspartate Aminotransferase to Platelet Ratio Index for Parenteral Nutrition-Associated Cholestasis in Premature Infants with Intestinal Perforation. Journal of Parenteral and Enteral Nutrition. https://doi.org/10.1177/0148607117722755

[46] National Library of Medicine HSDB Database (2017). https://www.ncbi.nlm.nih.gov/pmc/articles/PMC4922293/

[47] El-Nahhal, Y. (2003) Adsorption Mechanism of Chloroacetanilide Herbicides to Modified Montmorillonite. Journal of Environmental Science and Health B, 38, 
591-604. https://doi.org/10.1081/PFC-120023517

[48] El-Nahhal, Y. (2003) Persistence, Mobility, Efficacy and Safety of Chloroacetanilide Herbicide Formulation under Field Conditions. Environmental Pollution, 124, 33-38. https://doi.org/10.1016/S0269-7491(02)00431-1

[49] El-Nahhal, Y. (2003) Adsorptive Behavior of Acetochlor on Organoclay Complexes. Bulletin of Environmental Contamination and Toxicology, 70, 1104-1111. https://doi.org/10.1007/s00128-003-0096-Z

[50] EL-Nahhal, Y., Kerkez, M.F.S. and Abu Heen, Z. (2015) Toxicity of Diuron, Diquat and Terbutryn Cyanobacterial Mats. Ecotoxicology and Environmental Contamination, 10, 71-82. https://doi.org/10.5132/eec.2015.01.11

[51] El-Nahhal, Y., Awad, Y. and Safi, J. (2013) Bioremediation of Acetochlor in Soil and Water Systems by Cyanobacterial Mat. International Journal of Geosciences, 4, 880-890. https://doi.org/10.4236/ijg.2013.45082

[52] El-Nahhal, Y. and EL-dahdouh, N. (2015) Toxicity of Amoxicillin and Erythromycin to Fish and Mosquito. Ecotoxicology and Environmental Contamination, 10, 13-21. https://doi.org/10.5132/eec.2015.01.03

[53] El-Nahhal, Y. and Hamdona, N. (2015) Phytotoxicity of Alachlor, Bromacil and Diuron as Single or Mixed Herbicides Applied to Wheat, Melon, and Molokhia. SpringerPlus, 4, 364. https://doi.org/10.1186/s40064-015-1148-7

[54] EL-Nahhal, Y., EL-Najjar, Sh. and Afifi, S. (2015) Toxicity of Carbaryl, Chlorpyrifos and Diuron to Different Aquatic Organisms. Toxicology International, 22, 45-53. https://doi.org/10.4103/0971-6580.172256

[55] El-Nahhal, Y. and Hams, Sh. (2017) Effects of Bromacil, Malathion and Thiabendazole on Cyanobacteria Mat Growth. International Journal of Applied Science-Research and Review, 4, 1-9.

[56] El-Nahhal, Y., Abadsa, M. and Affifi, S. (2013) Adsorption of Diuron and Linuron in Gaza Soils. American Journal of Analytical Chemistry, 4, 94-99.

https://doi.org/10.4236/ajac.2013.47A013

[57] El-Nahhal, Y., Abadsa, M. and Affifi, S. (2014) Leaching Potential of Diuron and Linuron in Gaza Soils. American Journal of Plant Sciences, 5, 4040-4049. https://doi.org/10.4236/ajps.2014.526422

[58] El-Nahhal, Y. (2017) Risk Factors among Greenhouse Farmers in Gaza Strip. Occupational Diseases and Environmental Medicine, 5, 1-10. https://doi.org/10.4236/odem.2017.51001

[59] El-Nahhal, Y., Wheidi, B. and El-Kurdi, S. (2016) Development of Ecologically Acceptable Chlorpyrifos Formulation for Effective and Safe Application. Journal of Encapsulation and Adsorption Sciences, 6, 91-108. https://doi.org/10.4236/jeas.2016.63008

[60] El-Nahhal, Y., Lagaly, G. and Rabinovitz, O. (2005) Organo-Clay Formulations of Acetochlor: Effect of High Salt. Journal of Agricultural and Food Chemistry, 53, 1620-1624. https://doi.org/10.1021/jf040383a

Nir, S., Undabeytia, T., Yaron, D., El-Nahhal, Y., Polubesova, T., Serban, S., Rytwo, G., Lagaly, G. and Rubin, B. (2000) Optimization of Adsorption of Hydrophobic Herbicides on Montmorillonite Preadsorbed by Monovalent Organic Cations: Interaction between Phenyl Rings. Environmental Science and Technology, 34, 1269-1274.

[61] Nir, S., El-Nahhal, Y., Undabeytia, T., Rytwo, G., Polubesova, T., Mishael, Y., Rabinovitz, O. and Rubin, B. (2006) Clays and Pesticides. In: Bergaya, F., Theng, B.K.G. 
and Lagaly, G., Eds., Handbook of Clay Science, Elsevier, Amsterdam, 685-699.

[62] Rubin, B., El-Nahhal, Y., Nir, S. and Margulies, L. (2001) Slow Release Formulations of Pesticides. Patent No. US6,261,997 B1.

[63] Abed, M.A., Safi, M.N., Köster, J., Beer, D., El-Nahhal, Y., Rullkötter, J. and Garcia-Pichel, F. (2002) Microbial Diversity of a Heavily Polluted Microbial Mat and Its Community Changes Following Degradation of Petroleum Compounds. Applied Environmental Microbiology, 68, 1674-1683. https://doi.org/10.1128/AEM.68.4.1674-1683.2002

[64] El-Nahhal, Y., Nir, S., Serban, C., Rabinowitz, O. and Rubin, B. (2000) Montmorillonite-Phenyltrimethylammonium Yields Environmentally Improved Formulations of Hydrophobic Herbicides. Journal of Agricultural and Food Chemistry, 48, 4791-4801. https://doi.org/10.1021/jf000327j

[65] Kaschl, A., El-Nahhal, Y., Abu Mourad, T., Tubail, Kh., Safi, J., Hadar, Y., Chen, Y. and Roemheld, V. (1998) Long Term Field Experiment to Examine the Agricultural Application of Municipal Solid Waste Compost in Gaza Strip. Proceedings of Verband Deutscher Landwirtschaftlicher Untersuchungsund forschungsanstalten, Eiladung, KongreBband, 251-254.

[66] El-Nahhal, Y., Nir, S., Margulies, L. and Rubin, B. (1999) Reduction of Photodegradation and Volatilization of Herbicides in Organo-Clay Formulations. Applied Clay Science, 14, 105-119. https://doi.org/10.1016/S0169-1317(98)00053-2

[67] Polubesova, T., Nir, S., El-Nahhal, Y., Gerstl, G., Serban, C., Rabinovitz, O. and Rubin, B. (2002) Sorption of Neutral and Anionic Herbicides on Organoclays for Reduced Leaching in Soil. 3rd International Conference on Water Resources and Environmental Research, Vol. 2, 435-439.

[68] El-Nahhal, Y., Safi, M., Tubail, K. and Safi, J. (2013) Effect of Treated Wastewater Irrigation on Plant Growth and Soil Properties in Gaza Strip Palestine. American Journal of Plant Science, 4, 1736-1743. https://doi.org/10.4236/ajps.2013.49213 